\title{
Utilization of Poultry Slaughterhouses (PSh) Waste as a By-product of Protein Sources to Create the Environmental Friendly Livestock Systems in Makassar, South Sulawesi, Indonesia
}

\author{
Muhammad Irfan Said ${ }^{1}$, Effendi Abustam ${ }^{1}$, Wempie Pakiding ${ }^{1}$ and Muhammad \\ Zain Mide $^{2}$
}

\begin{abstract}
Livestock waste is one of the important problems in a livestock farming system. Various efforts was needed to reduce waste production. The use of waste is one of solution in reducing waste production to create an environmentally friendly livestock farming system. Utilization of livestock waste from PSh as feed ingredients for alternative protein sources can reduce the cost of feed use. This has an impact on a more efficient livestock business. The feather from the poultry contains high protein compounds. The application of waste from the poultry feather as a source of animal feed to improve the quality of quail meat has not been widely reported. The aim of the study was to examine the effect of giving feather waste extract (FWE) on the quality of thigh meat (Bicep femoris) for quail. A total of 100 heads quails, male, were used as samples. A total of 4 types of FWE administration treatments have been applied. Four types of FWE treatment have been applied in this study, namely: $\left(F_{A}=0 \% ; F_{B}=1 \% ; F_{C}=1.5 \%\right.$ and $\left.F_{D}=2 \%\right)$. Each treatment unit was repeated 5 times with 5 heads quail samples/treatment. The results showed that the application of FWE at different levels had a significant effect $(\mathrm{p}<0.05)$ on cooking loss $(\mathrm{CL})$ and shear force $(\mathrm{SF})$ of thigh meat (Bicep femoris), whereas in water holding capacity (WHC) it did not show a significant effect $(\mathrm{p}>0.05)$. The value of the WHC of thigh meat (Biceps femoris) is in the range of $33.33 \pm 1.65 \%$ $42.07 \pm 5.01 \%$, MSF of $0.40 \pm 0.05-0.93 \pm 0.18 \mathrm{~kg} / \mathrm{cm}^{2}$ and CL of $6.10 \pm 2.70-19.90 \pm 4.51 \%$. An application of $2 \% \mathrm{FWE}$ in feed mixtures showed better meat quality of thigh meat (Bicep femoris). An application of FWE as a protein source for animal feed can be improve the environmental sustainability and create a more efficient livestock business.
\end{abstract}

Keywords: Poultry slaughterhouse (PSb), By-product, Protein, Feather waste extract (FWE), Environmental friendly

\section{Introduction}

The existence of the livestock industry lately has been the spotlight of the government, especially those dealing with the environment. The existence of the livestock industry has been claimed by the United Nations as one of the industries contributing to environmental pollution (FAO, 2006). The waste produced by the livestock industry is feared to have an impact on humans, both as workers and communities around the industry.

One of the livestock industries that has the potential to produce waste is poultry slaughterhouses (PSh). The PSh is one of the industries that produce a lot of waste. One of the wastes produced are chicken feathers. Chicken feathers are composed of a large amount of protein so that it has the potential to be used as animal feed ingredients.

\footnotetext{
${ }^{1}$ Department of Animal Production, Faculty of Animal Science, Hasanuddin University

2Department of Animal Feed and Nutrition, Faculty of Animal Science, Hasanuddin University
} 
However, the digestibility of proteins from feathers is very low.

One type of the bird that can use feather meal as a feed ingredient is quail (Coturnix coturnix). In Indonesia, quail is a type of bird that is quite popular. It has characteristics such as: unable to fly, smaller body size and also a short legged form. Quail is one type of the bird that widely cultivated. Based on its population, quail is a type of livestock that widely developed in Indonesia. The total population is around 14,427,000 (Ministry of Agriculture, 2017). Quail is a type of the livestock that also developed in developing countries, such as Europe and Latin America. The quail and egg meat are processed into many food products (Ikhlas et al., 2011; Galíndez et al., 2010; Purohit \& Mohan 2016). Feed needs consist of $60 \%$ of the total cost requirements in a quail livestock industry. About $70 \%$ of quail's ability is better at utilizing feed nutrients (Zancanela et al., 2015). The ability of the digestive process of proteins in the digestive tract is influenced by the process of gastric and pancreatic secretions (Yu et al., 2002). The addition of exogenous proteases causes an increase in growth performance. The process can be influenced by energy digestibility and amino acids (Cowieson \& Roos, 2014). One source of poultry farm waste is feather. The feather has a high protein content but very low digestibility. Feed digestibility affects meat quality. The level of absorption of food substances in the body of livestock affects the quality of quail meat. Protein levels in quail blood are not affected by changes in protein in feed partially (Bovera et al., 2007). The purpose of this study was to examine the effect of giving feathers on poultry feather extract on the performance of quail meat in the thigh muscle (Bicep femoris).

\section{Materials and Methods}

\subsection{Research materials}

A total of 100 heads local quails (Coturnix coturnix) without sexing were used as research objects. Research objects using quail with body weight 30-36g, age 7 days. Feathers meal were obtained from poultry slaughterhouses (PSh), Daya, Makassar City, South Sulawesi, Indonesia. Feathers were extracted using a combination of chemical with pressurized heating hydrolysis techniques. The concentrate feed was prepared by isoprotein. The cages were made in the form of plots measuring $30 \mathrm{~cm} \times 20 \mathrm{~cm} \times 30 \mathrm{~cm}$. The ingredients were used in the preparation of feed consisted of feather extract, corn meal, coconut, soybean meal, rice bran, fish meal, vitamins and minerals.

\subsection{Research methods}

\subsubsection{Design of research}

Completely randomized design (CRD) of Unidirectional patterns was used as the basic design in this research. A total of 4 treatments of feather waste extract (FWE) level were applied, which was repeated 5 times $\left(\mathrm{F}_{\mathrm{A}}=0 \% ; \mathrm{F}_{\mathrm{B}}=1 \% ; \mathrm{F}_{\mathrm{C}}=1.5 \%\right.$ and $\mathrm{F}_{\mathrm{D}}=$ $2 \%$ ). The study was conducted for 1 month.

\subsubsection{Implementation of research}

A total of 5 quails were included in each cage plot. A total of 3 stages of activities were applied in this study, namely: (1) preparation stage, (2) treatment and (3) field data analysis. Provision of feed ingredients, making cages, and stocking chickens is 
the initial preparation stage. In addition, the process of cleaning cages, weather protectors, lights, feed and drink places and the sterilization process were carried out. Every week a weighing process was carried out. The feeding process was carried out every day and drinking water was given daily without being restricted.

\subsubsection{Data analysis of research}

ANOVA was used to analyze the research data, while further testing uses the Duncan's test (Steel \& Torrie, 1991).

\section{Result and Discussions}

\subsection{Water Holding Capacity}

The water capacity holding capacity (WHC) by meat protein is the ability of meat protein to bind water particles. The WHC also has an understanding of the amount of water added as long as there is a force influence, such as meat cutting, heating, grinding, and pressure. In general, meat has the ability to absorb water spontaneously from a liquid-containing environment. The description of the differences of WHC of quail meat with different concentrations was presented in Figure 1.

Meat is all animal tissue that can be consumed without causing health problems. Protein is the largest component of meat. Meat contains $68-80 \%$ of water, $16-22 \%$ of protein and partly consists of non-protein soluble substances and then $2-5 \%$ of fat. One of the important physical properties of meat is WHC. WHC is the ability of meat protein to bind water particles. The bound water consists of three compartments, namely: 1) chemically bound water, 2) the layer is hydrophilically bound and 3) free water molecules. The value of WHC affects the quality of meat (Soeparno, 1994).

The differences of the species, types of feed given, age of animals, muscle conditions, animal transportation activities, storage temperature, room humidity, storage methods, preservation, gender, health conditions, conditions before the cutting process and intramuscular fat levels have affect to WHC values (Soeparno, 1994). The results of the statistical analysis on the Figure 1 showed that the difference in levels of feather waste extract (FWE) no significant effect ( $\mathrm{p}>0.05$ ) on WHC values.

The increased of the feed consumption results in an increase in relative protein absorption in energy. This is due to an increase in the rate of movement of feed particles. The other factors can be occur because of the degradation process in the digestive tracts of animal. The test results showed that the value of WHC on the thigh meat (Biceps femoris) of quail was in the range of $33.33 \pm 1.65 \%-42.07 \pm 5.01 \%$. Increasing the level of administration of FWE tends to increase the value of WHC. The phenol groups that can reduce protein oxidation related to WHC values (Estévez et al., 2008). The quail has a more efficient and energy level of protein use than other species (Jordão-Filho et al., 2011). 


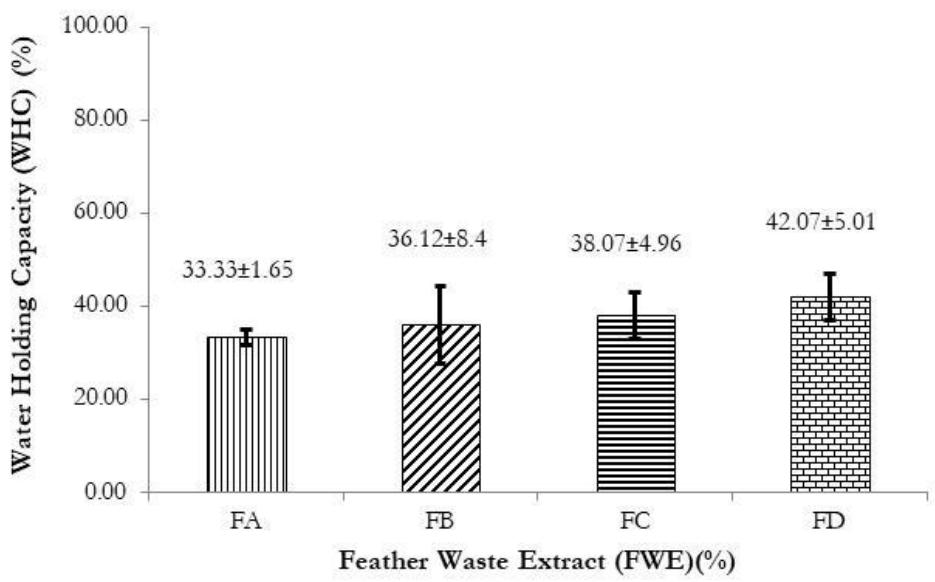

Figure 1. Comparison of the value of water holding capacity (WHC)(\%) of thigh meat (Biceps femoris) from the quail through the provision of $F W E$ at different levels; level of $F W E(\%)(F A=0 \%$; $F B=1 \%$; $F C=1.5 \%$; $F D=2 \%)$

\subsection{Meat Shear Force}

The value of meat shear force (MSF) is related to tenderness. The results of the testing samples using equipment is one expression of the tenderness of meat. This is a subjective assessment. The high of MSF value in the meat testing indicates that the meat has a low tenderness level. Conversely, the results a low MSF value indicate that the meat has a high of tenderness (Miller et al., 2001). The comparison of MSF values of meat from quail thigh muscle (Biceps femoris) in different FWE was presented in Figure 2.

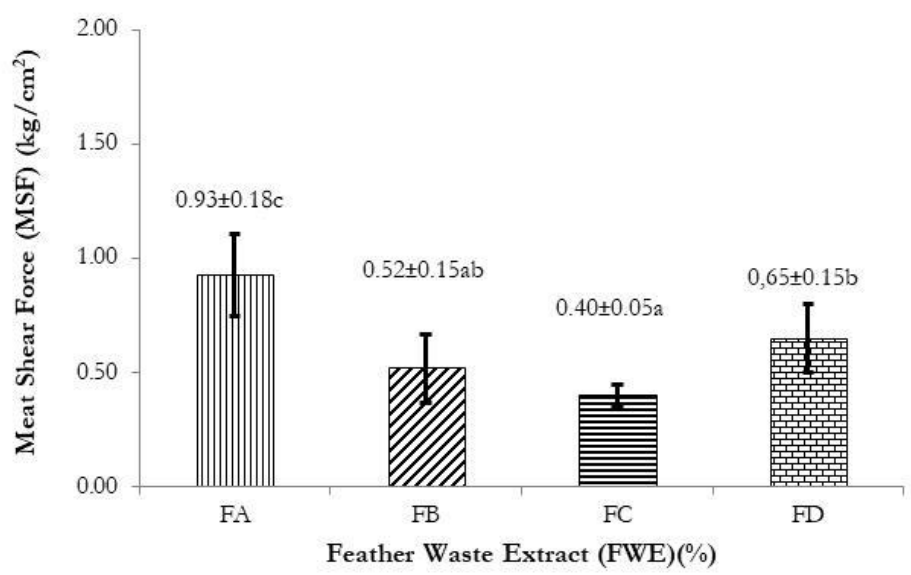

Figure 2. Comparison of the value of meat shear force $(M S F)(\mathrm{kg} / \mathrm{cm} 2)$ of thigh meat (Biceps femoris) from the quail through the provision of FWE at different levels; level of $\mathrm{FWE}(\%)$ in the feeding formula ( $\mathrm{F} A=0 \%$; $F B=1 \% ; F C=1.5 \% ; F D=2 \%) ;$ a,b,c The values followed by different alphabet at each treatment showed significant differences $(p<0.05)$. 
The tenderness phenomenon in meat is one of the factors that determine consumer acceptance. Tenderness can affect to customer satisfaction especially for palatability of meat. Tender meat will be liked by consumers. This certainly determines to the selling price of meat (Savell et al., 1987; Savell et al., 1989; Smith et al., 1987). The results of statistical analysis (Figure 2) show that the difference in the level of FWE has significant effect $(\mathrm{p}<0.05)$ to the value of the MSF especially in thigh meat (Biceps femoris) of quail. The results showed a range of $0.40 \pm 0.05-0.93 \pm 0.18 \mathrm{~kg} / \mathrm{cm}^{2}$ in Biceps femoris of quail. Meat tenderness will provide important economic value for producers (Boleman et al., 1997). Meat tenderness influenced by the process of converting muscle to meat. There are three phases in the process of converting muscle to meat. (1) pre-rigor mortis phase, (2) rigor mortis and (3) postmortem (Tantamacharik et al., 2018). This process is related to several factors such as muscle type, individual animals, and animal species (Becila et al., 2010; Lana et al., 2015; Lana \& Zolla 2016; Malheiros et al., 2018). There are 3 factors that determine to the meat tenderness, namely hardness, the process towards tenderness and the tenderness phase (Hopkins \& Geesink, 2009). The process of proteolysis after the death of animal is responsible for the process of tenderness of the meat (Hopkins \& Thompson, 2002; Koohmaraie \& Geesink, 2006; Ouali et al., 2006).

\subsection{Cooking Loss}

Cooking loss (CL) is a phenomenon that occurs in meat which is the meat losses occurs during to the cooking process. The CL value can be used to estimate the amount of water in the meat. This result can be also the basis for estimating the amount of nutrient loss in the meat during cooking process. The meat that has a low CL has to the better quality of meat. This is related to the low loss of nutrients in the meat. The value of CL was influenced by the phenol content in the feed. Phenol content in feed can reduce to the occurrence of protein oxidation (Mehdipour et al., 2013). Comparison of the CL values of quail meat treated with the different of FWE was shown in Figure 3.

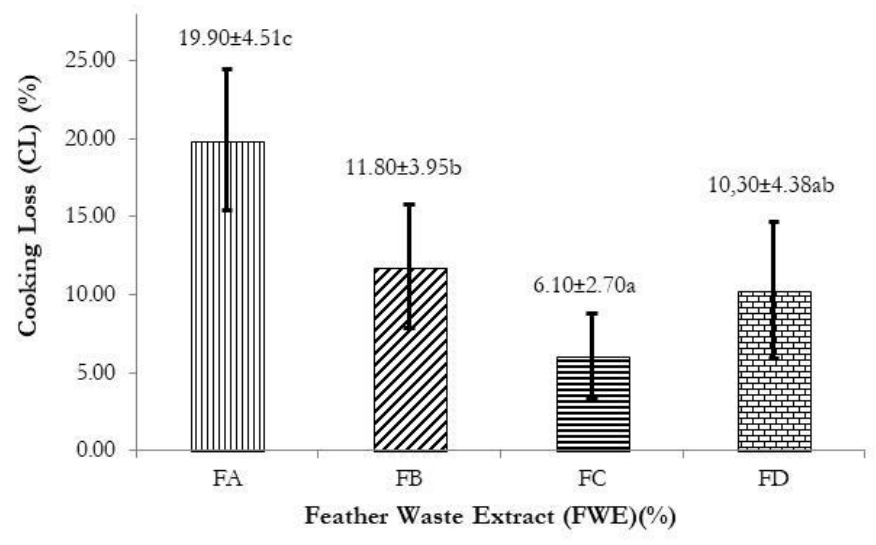

Figure 3. Comparison of the value of cooking loss (CL)(\%) of thigh meat (Biceps femoris) from the quail through the provision of $\mathrm{FWE}$ at different levels; level of $\mathrm{FWE}(\%)$ in the feeding formula $(\mathrm{F} A=0 \%$; $\mathrm{FB}=1 \%$; $F C=1.5 \%$; $F D=2 \%) ; a, b, c$ The values followed by different superscripts at each treatment showed significant differences $(p<0.05)$. 
The results of the statistics analysis showed that the application of FWE in quail feed showed a significant effect $(\mathrm{p}<0.05)$ on the CL value of Biceps femoris of quail meat (Figure 3). The CL test results are in the range of $6.10 \pm 2.70-19.90 \pm 4.51 \%$. The increasing to the applications of FWE tend to decrease of the CL value. This can be caused by changes in the chemical and physical composition of the Biceps femoris during to the storage process (Soeparno, 1994). The CL was influenced by $\mathrm{pH}$, sarcomere length of muscle fibers, muscle fibers, contraction status, sample size and weight and cross section on meat. The long cooking process will be reduce to the length of muscle fibers. The cooking process decreases linearly with increasing age in a animal. The difference of CL is also influenced by breed of the animal. Intramuscular fat inhibits the release of meat fluids during to the cooking process. Feed consumption can affect to the size of CL. Protein is related to the level of oxidative stress. The protein functions as an indicator of oxidative stress in postmortem tissue. Oxidative stress affects to the process of proteolysis and degradation of structural proteins such as desmin, troponin, actin, and myosin (Lana \& Zolla, 2016; Picard \& Gagaoua, 2017; Malheiros et al., 2018). Flavor, juiciness and tenderness affect to the acceptability (delicious taste) of meat (Thompson, 2002).

\section{Conclusion}

The feather waste obtained from the poultry slaughterhouses (PSh) have the potential to be processed into feather waste extract (FWE). It is one of solution in utilizing by products livestock to improve environmental conditions. The FWE can be applied as a feed ingredient for protein source in quail feed. The application of FWE in quail feed (Coturnix coturnix) to reach a level of $2 \%$ markedly reduced cooking losses (CL) and meat shear force (MSF) during the research process. However, the application of FWE does not have an effect on water holding capacity (WHC) of the thigh meat from quail. The application $2 \%$ of FWE in the feed of quail shows better meat quality than the other levels and controls. The application of FWE as a protein source for animal feed encourages efforts to reduce livestock waste production. The use of feather waste creates an environmental friendly on the livestock system.

\section{Acknowledgement}

The authors would like to thanks the Ministry of Research, Technology and Higher Education, as well as the Rector of Hasanuddin University, Head of Institute for Research and Community Service (IRCS) who supported this research activity through for research program "Penelitian Terapan Unggulan Perguruan Tinggi (PTUPT)". The authors would like to thanks the students (Arham, Sofyan Basri and Fulkin Alen) for their cooperation in conducting this research.

\section{References}

Becila, S., Herrera-Mendez, C.H., Coulis, G., Labas, R., Astruc, T., Picard, B., \& Ouali, A. (2010). Postmortem muscle cells die through apoptosis. European Food Research and Technology, 231(3), 485-493. 
Boleman, S.J., Miller, R.K., Taylor, J.F., Cross, H.R., Wheeler, T.L., Koohmaraie, M., Shackelford, S.D., Miller, M.F., West, R.L., Johnson, D.D. \& Savell, J.W. (1997). Consumer evaluation of beef of known categories of tenderness. J. Anim. Sci, 75,1521-1524.

Bovera F, Moniello, G., Riu, N., Meo, C., Pinna, W. \& Nizza, A. (2007). Effect of diet on the metabolic profile of ostriches (Strutbio camelus var domesticus). Trop Anim Health Prod, 39, 265-270.

Cowieson, A.J. \& Roos, F.F. (2014). Bioefficacy of a mono-component protease in the diets of pigs and poultry: a meta-analysis of effect on ileal amino acid digestibility. J. Appl. Anim. Nutr, 2, e13-e20.

Estévez, M., Kylli, P., Puolanne, E., Kivikari, R. \& Heinonen, M. (2008). Oxidation of skeletal muscle myofibrillar proteins in oil-in-water emulsions: interaction with lipids and eff ect of selected phenolic compounds. J. Agric. Food Chem, 56, 10933-10940.

FAO. (2006). Livestock's Long Shadow. Environmental issues and options. Food and Agriculture Organization (FAO) Of The United Nations, Rome. http://www.fao.org/docrep/010/a0701e/a0701e00.HTM . [Accessed March 05, 2019]

Galíndez, R., De Basilio, V., Martínez, G., Vargas, D., Uztariz, E. \& Mejía, P. (2010). Eff ect of hatching month, egg physical characters and storage, on embryonic mortality in japanese quails (Coturnix coturnix japonica). Zootec. Trop, 28, 17-24.

Hopkins, D.L. \& Geesink, G.H. (2009). Protein degradation post mortem and tenderisation. In M. Du, \& R. McCormick (Eds.). Applied muscle biology and meat science (pp. 149-173). USA: CRC Press, Taylor \& Francis Group.

Hopkins, D. L. \& Thompson, J.M. (2002). Factors contributing to proteolysis and dis- ruption of myofibrillar proteins and the impact on tenderisation in beef and sheep meat. Australian Journal of Agricultural Research, 53, 149-166.

Ikhlas, B., Huda, N. \& Noryati, I. (2011) Chemical composition and physicochemical properties of meatballs prepared from mechanically deboned quail meat using various types of flour. Int. J. Poult. Sci, 10, $30-37$.

Jordão-Filho, J., Silva, J.H.V., Silva, C.T., Costa, F.G.P., Sousa, J.M.B. \& Givisiez, P.E.N. (2011). Energy requirement for maintenance and gain for two genotypes of quails housed in different breeding rearing systems. R. Bras. Zootec, 40, 2415-2422.

Koohmaraie, M. \& Geesink, G.H. (2006). Contribution of postmortem muscle biochemistry to the delivery of consistent meat quality with particular focus on the calpain system. Meat Science, 74, 34-43.

Lana, A. \& Zolla, L. (2016). Proteolysis in meat tenderization from the point of view of each single protein: A proteomic perspective. Journal of Proteomics, 147, 85-97.

Lana, A., Longo, V., Dalmasso, A., D’Alessandro, A., Bottero, M.T. \& Zolla, L. (2015). Omics integrating physical techniques: Aged Piedmontese meat analysis. Food Chemistry, 172, 731-741.

Malheiros, J.M., Braga, C.P., Grove, R.A., Ribeiro, F.A., Calkins, C.R., Adamec, J. \& Chardulo, L.A.L. (2018). Influence of oxidative damage to proteins on meat tenderness using a proteomics approach. Meat Science, 148, 64-71.

Mehdipour, Z., Afsharmanesh, M. \& Sami, M. (2013). Eff ects of dietary symbiotic and cinnamon (Cinnamomum verum) supplementation on growth performance and meat quality in Japanese quail. Livest. Sci, 154, 152-157.

Miller, M.F., Carr, M.A., Ramsey, C.B., Crockett, K.L. \& Hoover, L. (2001). Consumer thresholds for establishing the value of beef tenderness. J. Anim Sci, 79, 3062-3068.

Ministry of Agriculture. (2017). Livestock and Animal Health Statistics in 2017. Ministry of Agriculture Republic of Indonesia, Jakarta.

Ouali, A., Hernan-Mendez, C.H., Coulis, G., Beclia,S., Boudjellal, A. \& Aubury, L. (2006). Revisiting the conversion of muscle into meat and the underlying mecha- nisms. Meat Science, 74, 44-58.

Picard, B. \& Gagaoua, M. (2017). Proteomic Investigations of Beef Tenderness. Proteomics in Food Science, 177-197.

Purohit, A.S., Reed, C. \& Mohan, A. (2016). Development and evaluation of quail breakfast sausage. LWTFood Sci. Tech, 69, 447-453.

Savell, J.W., Branson, R.E., Cross, H.R., Stiffler, D.M., Wise, J.W., Griffin, D.B. \& Smith, G.C. (1987). National Consumer Retail Beef Study: Palatability evaluations of beef loin steaks that differed in marbling. J. Food Sci, 52, 517-519, 532. 
Savell, J.W., Cross, H.R., Francis, J.J., Wise, J.W., Hale, D.S., Wilkes, D.L. \& Smith, G.C. (1989). National Consumer Retail Beef Study: Interaction of trim level, price and grade on consumer acceptance of beef steaks and roasts. Food Qual, 12, 251-274.

Smith, G.C., Savell, J.W., Cross, H.R., Carpenter, Z.L., Murphey, C.E., Davis, G.W., Abraham, H.C., Parrish, F.C. \& Berry, B.W. (1987) Relationship of USDA quality grades to palatability of cooked beef. $J$. Food Qual, 10, 269-287.

Soeparno. (1994). Ilmu dan Teknologi Daging. Gadjah Mada University Press, Yogyakarta.

Steel, R.G.D. \& Torrie, J.H. (1991). Principle and Procedure of Statistics. $2^{\text {nd }} . e d$. International Book Company, Tokyo.

Tantamacharik, T., Carne, A., Agyei, D., Birch, J. \& Bekhit A.E.D.A. (2018). Use of Plant Proteolytic Enzymes for Meat Processing. In: Guevara M., Daleo G. (eds) Biotechnological Applications of Plant Proteolytic Ensymes. Springer, Cham, 43-67

Thompson, J. M. (2002). Managing meat tenderness. Meat Science, 62, 295-308.

Yu, B., Lee, T.T.T. \& Chiou, P.W.S. (2002). Effects of sources of protein and enzyme supplementation on protein digestibility and chyme characteristics in broilers. Br. Poult. Sci, 43, 424-431.

Zancanela, V., Marcato, S.M., Furlan, A.C., Grieser, D.O., Ton, A.P.S., Batista, E., Perine, T.P., Del Vesco, A.P. \& Pozza, P.C. (2015). Models for predicting energy requirements in meat quail. Livestock Science, 171, 12-19. 